\title{
Efficacy, patient-doctor relationship, costs and benefits of utilizing telepsychiatry for the management of post- traumatic stress disorder (PTSD): a systematic review
}

\author{
Anthony Paulo Sunjaya, ${ }^{1}$ (D) Arlends Chris, ${ }^{1}$ Dewi Novianti ${ }^{2}$
}

\begin{abstract}
Introduction: Post-traumatic stress disorder (PTSD) is one of the most common psychiatric disorders found among victims of disaster, kidnapping, accidents, sexual assaults and war in Indonesia. However, lacking and unequal distribution of psychiatric medical personnel remains a barrier to its management. This review aims to introduce and evaluate the potential contribution of telepsychiatry to the management of PTSD based on published literature.

Methods: Original studies were obtained from PubMed, Science Direct, ProQuest, High Wire, and Elsevier Clinical Key databases.

Results: A total of 125 articles were found, of which 15 articles (12 randomized controlled trials, 2 open trials and 1 pilot study) fulfilled the inclusion criteria. A total of 991 subjects were found with a follow-up period ranging between 5 weeks and 18 months. Telepsychiatry is an innovative use of technology to aid the delivery of PTSD treatments in areas difficult to reach. The quality of care given by telepsychiatry both through video conferencing as well as web- and application-based is comparable to that of face-to-face therapy. Patient satisfaction, quality of doctor-patient relationship also remains high, with lower costs and shorter therapeutic time when compared to face-to-face therapy.

Conclusion: Various studies have shown that telepsychiatry is an effective solution for the management of PTSD. Studies have also reported that the quality of treatment through telepsychiatry is as effective as face-to-face therapy, with greater efficiency. Countries, especially those with a low patient-to-mental health professional ratio, should be encouraged to develop telepsychiatry systems to manage PTSD.

Keywords: Telepsychiatry, post-traumatic stress disorder, telemedicine.
\end{abstract}

\section{Introduction}

Globally, around $61 \%$ of males and $50 \%$ of females will face at least one traumatic event throughout their life. Traumatic events include war, violence (sexual violence, physical attacks, etc.), kidnappings, torture, terrorism, road accidents and natural disasters. Sexual violence, witnessing a tragic death or horrifying injury during one's childhood is also one of the main causes of lifelong trauma. ${ }^{1}$

The World Health Organization (WHO) in 2013 reported that an average $3.6 \%$ of the world's population suffers from post-traumatic stress disorder (PTSD), with a distribution of $28.5 \%$ in the Western Pacific and $27.4 \%$ in Southeast Asia. ${ }^{2}$ In Indonesia, the most recent national health survey conducted by the Ministry of Health in 2018

\footnotetext{
${ }^{1}$ Faculty of Medicine, Tarumanagara University, Jakarta, Indonesia. ${ }^{2}$ Department of Public Health and Family Medicine, Faculty of Medicine, Tarumanagara University, Jakarta, Indonesia.

Submitted Mar 22 2019, accepted for publication Jun 172019.

Suggested citation: Sunjaya AP, Chris A, Novianti D. Efficacy, patient-doctor relationship, costs and benefits of utilizing telepsychiatry for the management of post-traumatic stress disorder (PTSD): a systematic review. Trends Psychiatry Psychother. 2020;42(1):102-110. http://dx.doi.org/10.1590/2237-60892019-0024
} 
reported that the prevalence of psychiatric disorders was $9.8 \%$, rising from $6 \%$ in 2013 , although there were no specific data on the prevalence of PTSD. ${ }^{3}$ This may be a result of an increase in the number of sex-related cases, ${ }^{4}$ violent criminal offenses, ${ }^{5}$ road accidents, ${ }^{6}$ all of which are main triggers of PTSD. Furthermore, terrorism, forced evictions and increasing competition in life have also contributed to the rise in PTSD cases in Indonesia, especially in disaster-prone areas. ${ }^{7-9}$

PTSD is a psychiatric disorder caused by traumatic events or a series of traumatic events involving oneself, others or their loved ones and having resulted in death, serious injuries or both. ${ }^{10}$ Patients with PTSD show signs of anxiousness, fear, repeated flashbacks of the traumatic event, avoidance of objects, locations etc. associated with the event; they withdraw themselves emotionally (emotional numbing) and respond overwhelmingly to similar events. ${ }^{11-13}$

PTSD does not always appear immediately after the triggering event, but may appear within weeks or even 30 years after the event has occurred.10 Symptoms also fluctuate over time and especially worsen during periods of stress. Without proper management, only $30 \%$ of patients recover on their own, $40 \%$ will always present minor symptoms and $10 \%$ worsen over time. A poorer prognosis is observed among children and the elderly, due to their greater emotional vulnerability and poor coping mechanisms. ${ }^{10}$

Untreated PTSD has been proven to affect both cognitive and learning function. Patients with PTSD have difficulties in concentration, cognition and emotion management, which can negatively impact their interpersonal relations and impair their decision-making skills in life. PTSD also lowers work and academic achievements. In the end, PTSD can lower one's quality of life, productivity and inadvertently lead to huge social costs to society. ${ }^{14,15}$

Although PTSD leads to numerous negative consequences, patients with PTSD are often not managed adequately. This is potentially caused by lack of awareness among PTSD sufferers as well as difficulty receiving therapy, due to the scarcity of psychiatric medical resources. ${ }^{10,12,16}$

Currently, there are many different types of psychotherapy available for PTSD, such as prolonged exposure, cognitive behavioral therapy (CBT), and eye movement desensitization and reprocessing (EMDR), all of which have been proven effective in managing patients with PTSD. ${ }^{12}$ Psychotherapy does not involve the use of medications, but instead aims to change the way someone feels about the trauma that they have faced. ${ }^{10}$

The lack of psychiatric health professionals such as psychiatrists, clinical psychologists and psychiatric nurses, as well as limited access to and distribution of these services are among the several barriers in managing PTSD throughout the world, especially in developing countries. In 2018, it was reported that there were only 773 psychiatrists (0.32 per 100,000 population) and 451 clinical psychologists (0.15 per 100.000 population) in Indonesia, severely low numbers compared to the WHO recommendations of 1 psychologist and psychiatrist per 30,000 population or 3.33 per 100,000 population. Distribution of psychiatric care also remains uneven and mostly concentrated in urban areas. These factors have made PTSD treatment become rare and expensive in many developing countries, including Indonesia. ${ }^{12,16}$

\section{Telemedicine}

Telemedicine refers to the remote provision of medical services, i.e., distant from the medical professional, through the use of information technology to aid in the exchange of health information for the purpose of diagnosis, management and prevention of diseases, research and evaluation, and also to improve the knowledge of health professionals with the sole aim of improving health care for both the community and society. ${ }^{17}$ Telemedicine links doctors from a referral center/hospital to health professionals and patients elsewhere, in their homes, community health centers, etc., through the use of various telecommunication media such as satellite and fiber optics. ${ }^{18-20}$

In 2016, the WHO reported that $77 \%$ of 125 countries throughout the world had implemented telemedicine. One of the main reasons behind telemedicine use is its ability to provide health care to remote areas, which are difficult to reach by health professionals. ${ }^{21}$ Telemedicine is also able to facilitate training of volunteers as well as health professionals both in remote areas and during natural disasters. ${ }^{17,22}$ Hence, telemedicine has great potential in bridging the current need for better PTSD management throughout in Indonesia and similar developing countries with a low mental health professional to population ratio. The use of telemedicine for the care of psychiatric patients is referred to as telepsychiatry. 2,23,24 This review therefore aims to evaluate the potential of telepsychiatry as an alternative solution to overcome the barriers to better PTSD care in Indonesia and other countries.

\section{Materials and methods}

\section{Data source}

The databases searched to obtain the articles included PubMed, Science Direct, ProQuest, High Wire, 
and Elsevier Clinical Key. The search strategies used included availability of full text written in English and published from January 2003 to December 2017. The following keywords were used: "post-traumatic stress disorder or delayed stress disorder" and "telepsychiatry or telemedicine or telehealth or e-health or teleconsultation or video conference or telecare AND psychiatry." When multiple articles deriving from the same study were found, only the most recent publication was included. An approach based on title, abstract, and full text was used to evaluate the relevance of articles.

\section{Study selection}

Studies were included if they were original studies and if they had one of the following designs: randomized controlled trial (RCT), case-control study, and cohort study. Ideally, PTSD in the studies should be diagnosed in accordance to the criteria found in the Fifth Edition of the Diagnostic and Statistical Manual of Mental Disorders (DSM-5) by the American Psychiatric Association (APA). ${ }^{13}$

In addition, studies were included if: 1) they included patients with PTSD and management was carried out through telepsychiatry with any method or length of time; 2) parameters related to the control of symptoms, therapeutic alliance, economic effects were reported; 3) studies compared telepsychiatry use vs. routine care; or 4) studies compared patients treated with telepsychiatry vs. another type of management with placebo as control. Studies not meeting these criteria were excluded from this review.

\section{Results and discussion}

Our initial search resulted in 125 articles, of which 39 were excluded due to duplicate citations. Fifty-seven were then excluded on the basis of title and abstract. Of the remaining 29 studies, 13 were excluded because they did not meet the inclusion criteria, 2 reported on acute stress disorder and not PTSD, 4 were editorials, 5 studied substance abuse with PTSD rather than PTSD alone, and 2 were duplicate publications of the same study. Finally, 15 articles were found that fulfilled all of our inclusion criteria: 12 RCTs, 2 open trials, and 1 pilot study (Figure 1).

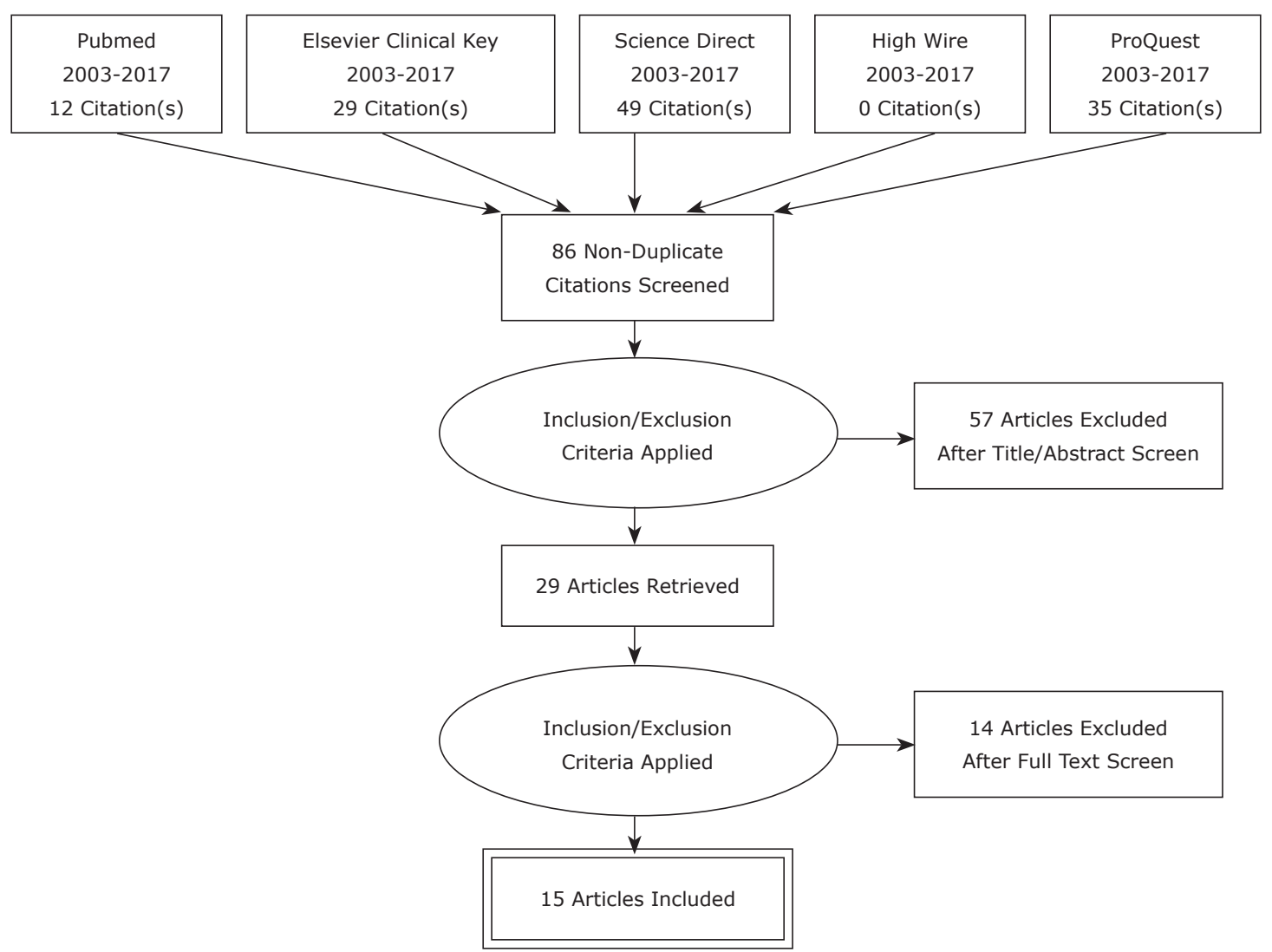

Figure 1 - Data selection flow chart 
Sample size varied across studies, ranging from $15^{25}$ to $241^{24}$ patients, with a follow-up duration ranging between 5 weeks ${ }^{26}$ and 18 months. ${ }^{27}$ The total number of subjects considering all studies was 991 . The majority of studies were published from 2010 onwards and conducted in developed nations. Five studies were conducted in Germany, ${ }^{25-29}$ three in Australia, ${ }^{30-32}$ two in Canada, ${ }^{23,24}$ and the remainder were one each from China, ${ }^{33}$ Iraq, $^{34}$ the Netherlands, ${ }^{35}$ the United States of America, ${ }^{36}$ and Sweden. ${ }^{37}$

\section{Effectiveness and quality of therapy}

Fourteen of the studies evaluated documented that the effectiveness of telepsychiatry was similar to that of face-to-face therapy, although with varying levels of improvements (Table 1 ).

Germain et al. compared CBT administered to PTSD patients face to face and through teleconference for 16-25 weeks and reported a significant reduction in frequency and severity of PTSD symptoms in both groups post-therapy. No significant differences in

Table 1 - Summary of telepsychiatry studies included in the review

\begin{tabular}{|c|c|c|c|c|c|c|c|}
\hline \multirow[b]{2}{*}{$\begin{array}{l}\text { Ref. } \\
\text { no. }\end{array}$} & \multirow[b]{2}{*}{ Title } & \multirow[b]{2}{*}{ Author } & \multirow[b]{2}{*}{ Country } & \multicolumn{3}{|c|}{ Methodology } & \multirow[b]{2}{*}{ Result } \\
\hline & & & & Design & Sample size & $\begin{array}{l}\text { Parameter } \\
\text { compared }\end{array}$ & \\
\hline 23 & $\begin{array}{l}\text { Effectiveness of } \\
\text { cognitive behavioural } \\
\text { therapy administered } \\
\text { by videoconference for } \\
\text { posttraumatic stress } \\
\text { disorder }\end{array}$ & $\begin{array}{l}\text { Germain } \\
\text { et al. }\end{array}$ & Canada & $\mathrm{RCT}$ & $\begin{array}{l}\text { Face-to-face } \\
31 \text { patients vs. } \\
\text { telepsychiatry } 16 \\
\text { patients }\end{array}$ & $\begin{array}{l}\text { SCID-IV } \\
\text { MPSS } \\
\text { BDI }\end{array}$ & $\begin{array}{l}\text { Significant improvements in PTSD } \\
\text { symptoms, level of depression, } \\
\text { anxiety, daily function and perception } \\
\text { of health in both groups. } \\
\text { No significant difference in } \\
\text { effectiveness between CBT face-to- } \\
\text { face vs. telepsychiatry. }\end{array}$ \\
\hline 24 & $\begin{array}{l}\text { Is telepsychiatry equivalent } \\
\text { to face-to-face psychiatry? } \\
\text { Results from a randomized } \\
\text { controlled equivalence trial }\end{array}$ & $\begin{array}{l}\text { O'Reilly } \\
\text { et al. }\end{array}$ & Canada & RCT & $\begin{array}{l}\text { Face-to-face } \\
254 \text { patients vs. } \\
\text { telepsychiatry } 241 \\
\text { patients }\end{array}$ & $\begin{array}{l}\text { BSI } \\
\text { GSI } \\
\text { CSQ }\end{array}$ & $\begin{array}{l}\text { Clinical outcome in face-to-face } \\
\text { and telepsychiatry equivalent } \\
\text { (improvement in GSI: } 6.9 \text { vs. } 7.2 \text { ). } \\
\text { No difference in patient satisfaction } \\
\text { between both groups. } \\
\text { Cost analysis showed } 10 \% \text { cost } \\
\text { savings in telepsychiatry group (total } \\
\text { cost USD } 108,549 \text { vs. USD } 88,311 \text { ). }\end{array}$ \\
\hline 25 & $\begin{array}{l}\text { Efficacy of an Internet- } \\
\text { based intervention for } \\
\text { posttraumatic stress } \\
\text { disorder in Iraq: a pilot } \\
\text { study }\end{array}$ & $\begin{array}{l}\text { Wagner } \\
\text { et al. }\end{array}$ & Germany & Pilot study & $\begin{array}{l}\text { Telepsychiatry } 15 \\
\text { patients }\end{array}$ & $\begin{array}{l}\text { PDS } \\
\text { HSCL-25 } \\
\text { Skala } \\
\text { Quality } \\
\text { of Life } \\
\text { (EUROHIS) }\end{array}$ & $\begin{array}{l}\text { Conducted with Arabic patients. } \\
\text { Significant improvement in symptoms } \\
\text { of PTSD, depression, anxiety. } \\
\text { Better quality of life post-therapy. } \\
\text { Effect size for PTSD Scale }(1.57) \text {, } \\
\text { depression (1.51), anxiety }(1.50) \text {, and } \\
\text { quality of life }(1.17) \text {. }\end{array}$ \\
\hline 26 & $\begin{array}{l}\text { Online working alliance } \\
\text { predicts treatment outcome } \\
\text { for posttraumatic stress } \\
\text { symptoms in Arab war- } \\
\text { traumatized patients }\end{array}$ & $\begin{array}{l}\text { Wagner } \\
\text { et al. }\end{array}$ & Germany & $\mathrm{RCT}$ & $\begin{array}{l}\text { Telepsychiatry } 55 \\
\text { patients }\end{array}$ & $\begin{array}{l}\text { PDS and } \\
\text { Working } \\
\text { Alliance } \\
\text { Inventory }\end{array}$ & $\begin{array}{l}\text { Telepsychiatry for } 45 \text { minutes, twice } \\
\text { weekly for } 5 \text { weeks (total of } 10 \\
\text { sessions). } \\
\text { High patient satisfaction throughout } \\
\text { study. } \\
\text { Better patient satisfaction correlated } \\
\text { with symptom improvement. }\end{array}$ \\
\hline 27 & $\begin{array}{l}\text { Long-term effects of an } \\
\text { internet-based treatment for } \\
\text { posttraumatic stress }\end{array}$ & $\begin{array}{l}\text { Knaevelsrud } \\
\text { \& Maercker }\end{array}$ & Germany & $\begin{array}{l}\text { Follow up } \\
\text { study after } \\
\text { RCT }\end{array}$ & $\begin{array}{l}34 \text { telepsychiatry } \\
\text { patients } 18 \text { months } \\
\text { post-therapy }\end{array}$ & $\begin{array}{l}\text { IES-R } \\
\text { DASS }\end{array}$ & $\begin{array}{l}\text { Pre and post-therapy data were } \\
\text { compared. } \\
\text { Improvements in PTSD, depression } \\
\text { and anxiety symptoms remained for } \\
18 \text { months post-therapy. } \\
\text { Only } 24 \% \text { needed additional face-to- } \\
\text { face therapy support. }\end{array}$ \\
\hline 28 & $\begin{array}{l}\text { Internet-based treatment for } \\
\text { PTSD reduces distress and } \\
\text { facilitates the development } \\
\text { of a strong therapeutic } \\
\text { alliance: a randomized } \\
\text { controlled clinical trial }\end{array}$ & $\begin{array}{l}\text { Knaevelsrud } \\
\text { \& Maercker }\end{array}$ & Germany & RCT & $\begin{array}{l}\text { WLC } 47 \text { patients } \\
\text { vs. telepsychiatry } \\
49 \text { patients }\end{array}$ & $\begin{array}{l}\text { IES-R } \\
\text { SCL-90 }\end{array}$ & $\begin{array}{l}\text { Conducted with German patients. } \\
\text { Significant difference in symptoms } \\
\text { between telepsychiatry and control } \\
\text { group. } \\
\text { High patient satisfaction ( } 86 \% \\
\text { satisfied, low dropout of } 16 \% \text { ). } \\
\text { Improvement remained during follow- } \\
\text { up } 3 \text { months post-therapy. }\end{array}$ \\
\hline
\end{tabular}

Continued on next page 
Table 1 (cont.)

\begin{tabular}{|c|c|c|c|c|c|c|c|}
\hline \multirow[b]{2}{*}{$\begin{array}{l}\text { Ref. } \\
\text { no. }\end{array}$} & \multirow[b]{2}{*}{ Title } & \multirow[b]{2}{*}{ Author } & \multirow[b]{2}{*}{ Country } & \multicolumn{3}{|c|}{ Methodology } & \multirow[b]{2}{*}{ Result } \\
\hline & & & & Design & Sample size & $\begin{array}{l}\text { Parameter } \\
\text { compared }\end{array}$ & \\
\hline 29 & $\begin{array}{l}\text { Brief Internet-based } \\
\text { intervention reduces } \\
\text { posttraumatic stress and } \\
\text { prolonged grief in parents } \\
\text { after the loss of a child } \\
\text { during pregnancy: a } \\
\text { randomized controlled trial }\end{array}$ & $\begin{array}{l}\text { Kersting } \\
\text { et al. }\end{array}$ & Germany & $\mathrm{RCT}$ & $\begin{array}{l}\text { WLC } 113 \text { patients } \\
\text { vs. telepsychiatry } \\
115 \text { patients }\end{array}$ & $\begin{array}{l}\text { IES-R } \\
\text { SCL-90 } \\
\text { Inventory of } \\
\text { Complicated } \\
\text { Grief }\end{array}$ & $\begin{array}{l}\text { Significantly better improvements in } \\
\text { PTSD symptoms, grief, depression and } \\
\text { anxiety in telepsychiatry group. } \\
\text { Improvements persisted for } 12 \\
\text { months post-therapy. }\end{array}$ \\
\hline 30 & $\begin{array}{l}\text { A therapist-assisted } \\
\text { cognitive behavior therapy } \\
\text { internet intervention } \\
\text { for posttraumatic stress } \\
\text { disorder: pre-, post- and } \\
\text { 3-month follow-up results } \\
\text { from an open trial }\end{array}$ & Klein et al. & Australia & Open trial & $\begin{array}{l}\text { Telepsychiatry } 22 \\
\text { patients }\end{array}$ & $\begin{array}{l}\text { PTSD Scale } \\
\text { MINI } \\
\text { Anxiety } \\
\text { Disorders } \\
\text { Interview } \\
\text { PCL } \\
\text { IES-R } \\
\text { DASS } \\
\text { WHOQOL- } \\
\text { BREF } \\
\text { TSQ } \\
\text { TAQ }\end{array}$ & $\begin{array}{l}69.2 \% \text { cured from PTSD after } 10 \\
\text { weeks of telepsychiatry. } \\
3 \text { months post-therapy, the } \\
\text { percentage of cured patients } \\
\text { increased to } 77 \% \text {. } \\
\text { Patient satisfaction of } 69 \% \text {. } \\
\text { High-quality doctor-patient } \\
\text { relationship }(87.5 \%) \text {. } \\
\text { Average total therapy time: } 194.5 \\
\text { minutes. }\end{array}$ \\
\hline 31 & $\begin{array}{l}\text { A therapist-assisted } \\
\text { Internet-based CBT } \\
\text { intervention for } \\
\text { posttraumatic stress } \\
\text { disorder: preliminary results }\end{array}$ & Klein et al. & Australia & Open trial & $\begin{array}{l}\text { Telepsychiatry } 16 \\
\text { patients }\end{array}$ & $\begin{array}{l}\text { IES-R } \\
\text { TAQ } \\
\text { TSQ }\end{array}$ & $\begin{array}{l}\text { Telepsychiatry only through e-mail. } \\
\text { Therapy for } 10 \text { weeks. } \\
\text { Significant improvements in PTSD } \\
\text { symptoms, good patient-doctor } \\
\text { relation. } \\
\text { Improvement in PTSD symptoms } \\
\text { reported. }\end{array}$ \\
\hline 32 & $\begin{array}{l}\text { Randomized controlled } \\
\text { trial of Internet-delivered } \\
\text { cognitive behavioral therapy } \\
\text { for posttraumatic stress } \\
\text { disorder }\end{array}$ & $\begin{array}{l}\text { Spence } \\
\text { et al. }\end{array}$ & Australia & $\mathrm{RCT}$ & $\begin{array}{l}\text { WLC } 21 \text { patients } \\
\text { vs. telepsychiatry } \\
23 \text { patients }\end{array}$ & $\mathrm{PCL}$ & $\begin{array}{l}\text { Telepsychiatry effective in reducing } \\
\text { PTSD symptoms ( } 61 \% \text { improved } \\
\text { in telepsychiatry group vs. } 21 \% \text { in } \\
\text { control group). } \\
\text { Efficient, only required therapeutic } \\
\text { time }<2 \text { hours (SD } 97 \text { minutes), } \\
\text { shorter than face-to-face therapy. } \\
\text { High patient satisfaction ( } 81 \% \\
\text { satisfied, } 95 \% \text { will recommend to } \\
\text { friends). } \\
\text { Improvements remained } 3 \text { months } \\
\text { post-therapy. }\end{array}$ \\
\hline 33 & $\begin{array}{l}\text { Chinese My Trauma } \\
\text { Recovery, a web-based } \\
\text { intervention for traumatized } \\
\text { persons in two parallel } \\
\text { samples: randomized } \\
\text { controlled trial }\end{array}$ & Wang et al. & China & RCT & $\begin{array}{l}\text { Telepsychiatry } 183 \\
\text { patients }\end{array}$ & $\begin{array}{l}\text { PDS } \\
\text { SCL-90 } \\
\text { CSE } \\
\text { PCC } \\
\text { SFI }\end{array}$ & $\begin{array}{l}\text { Telepsychiatry samples from both } \\
\text { urban and rural areas. } \\
\text { Improvement in PTSD symptoms for } \\
\text { both types of patients. } \\
\text { Improvements remain even } 3 \text { months } \\
\text { post-therapy during follow up. }\end{array}$ \\
\hline 34 & $\begin{array}{l}\text { Web-based psychotherapy } \\
\text { for posttraumatic stress } \\
\text { disorder in war-traumatized } \\
\text { Arab patients: randomized } \\
\text { controlled trial }\end{array}$ & $\begin{array}{l}\text { Knaevelsrud } \\
\text { et al. }\end{array}$ & Iraq & $\mathrm{RCT}$ & $\begin{array}{l}\text { WLC } 80 \text { patients } \\
\text { vs. telepsychiatry } \\
79 \text { patients }\end{array}$ & PDS & $\begin{array}{l}\text { Telepsychiatry for } 45 \text { minutes, twice } \\
\text { weekly for } 5 \text { weeks. } \\
62 \% \text { cured from PTSD post-therapy } \\
\text { (OR } 74.19 \text { ). } \\
\text { Improvements remained } 3 \text { months } \\
\text { post-therapy. }\end{array}$ \\
\hline 35 & $\begin{array}{l}\text { Interapy: a controlled } \\
\text { randomized trial of the } \\
\text { standardized treatment of } \\
\text { posttraumatic stress through } \\
\text { the internet }\end{array}$ & Lange et al. & $\begin{array}{l}\text { The } \\
\text { Netherlands }\end{array}$ & $\mathrm{RCT}$ & $\begin{array}{l}\text { WLC } 32 \text { patients } \\
\text { vs. telepsychiatry } \\
69 \text { patients }\end{array}$ & SCL-90 & $\begin{array}{l}\text { Conducted through Interapy platform: } \\
\text { psychoeducation, screening and } \\
\text { therapy for PTSD. } \\
\text { Significant improvements in trauma } \\
\text { symptoms and psychopathology in } \\
\text { telepsychiatry group vs. WLC. } \\
\text { Large effect size. } \\
\text { More than } 50 \% \text { of patients reported } \\
\text { significant improvements especially } \\
\text { in symptoms of depression and } \\
\text { avoidance. }\end{array}$ \\
\hline 36 & $\begin{array}{l}\text { Delivery of self-training } \\
\text { and education for stressful } \\
\text { situations (DESTRESS- } \\
\text { PC): a randomized trial of } \\
\text { nurse assisted online self- } \\
\text { management for PTSD in } \\
\text { primary care }\end{array}$ & Engel et al. & $\begin{array}{l}\text { United States } \\
\text { of America }\end{array}$ & $\mathrm{RCT}$ & $\begin{array}{l}\text { Face-to-face } \\
37 \text { patients vs. } \\
\text { telepsychiatry } 43 \\
\text { patients }\end{array}$ & PCL & $\begin{array}{l}\text { War veterans. } \\
\text { Effect of telepsychiatry for } 8 \text { weeks } \\
\text { better than standard face-to-face } \\
\text { therapy (effect size } 0.47 \text { measured } 12 \\
\text { weeks post-therapy). } \\
\text { Greatest improvement found } 12 \\
\text { months post-therapy, which reduced } \\
\text { when therapy was stopped. }\end{array}$ \\
\hline
\end{tabular}


Table 1 (cont.)

\begin{tabular}{|c|c|c|c|c|c|c|c|}
\hline \multirow[b]{2}{*}{$\begin{array}{l}\text { Ref. } \\
\text { no. }\end{array}$} & \multirow[b]{2}{*}{ Title } & \multirow[b]{2}{*}{ Author } & \multirow[b]{2}{*}{ Country } & \multicolumn{3}{|c|}{ Methodology } & \multirow[b]{2}{*}{ Result } \\
\hline & & & & Design & Sample size & $\begin{array}{l}\text { Parameter } \\
\text { compared }\end{array}$ & \\
\hline 37 & $\begin{array}{l}\text { Guided internet-delivered } \\
\text { cognitive behavior therapy } \\
\text { for post-traumatic: a } \\
\text { randomized controlled trial }\end{array}$ & $\begin{array}{l}\text { Ivarsson } \\
\text { et al. }\end{array}$ & Sweden & $\mathrm{RCT}$ & $\begin{array}{l}\text { WLC } 31 \text { patients } \\
\text { vs. telepsychiatry } \\
31 \text { patients }\end{array}$ & $\begin{array}{l}\text { CAPS } \\
\text { IES-R } \\
\text { PDS }\end{array}$ & $\begin{array}{l}\text { Eight weeks of therapy using online } \\
\text { module on psychoeducation, breathing } \\
\text { exercises, imaginal and in vivo } \\
\text { exposure, cognitive restructuring, } \\
\text { relapse prevention. } \\
\text { Feedback and therapist support once } \\
\text { weekly online. } \\
\text { Significant improvements in PTSD } \\
\text { symptoms, with effect size between } \\
\text { group IES-R ( } d=1.25 \text { ) and PDS } \\
\text { (d=1.24). } \\
\text { Improvements in symptoms remained } \\
1 \text { year post-therapy. }\end{array}$ \\
\hline
\end{tabular}

BDI = Beck Depression Inventory; BSI = Brief Symptom Inventory; CAPS = Clinician-administered PTSD Scale; CSE = Trauma Coping Self-Efficacy Scale; $\mathrm{CSQ}=$ Client Satisfaction Questionnaire; DASS = Depression, Anxiety Stress Scale; EUROHIS = Quality of Life Scale; GSI = Global Severity Index; HSCL-25 $=$ Hopkins Symptom Check List-25; IES-R = Impact of Event Scale Revised; MINI = Mini-International Neuropsychiatric Interview; MPSS = Modified PTSD Symptom Scale; OR = odds ratio; PCC = post-traumatic cognitive changes; PCL = PTSD Checklist; PDS = PTSD Scale; PTSD = post-traumatic stress disorder; $\mathrm{RCT}=$ randomized controlled trial; SCID-IV = Structured Clinical Interview; SCL-90 = Depression and Anxiety Symptom Checklist; SD = standard deviation; SFI = Social Functioning Impairment; TAQ = Therapeutic Alliance Questionnaire; TSQ = Treatment Satisfaction Questionnaire; WHOQOL-BREF = World Health Organization Quality of Life instrument-Abbreviated version; WLC = wait list control.

effectiveness were found between both groups. ${ }^{23,24,33}$ In a similar study by Klein et al. using online CBT, 69.2\% of PTSD patients showed significant post-therapy improvements in symptoms; that number increased to $77 \%$ at 3 months' post-therapy follow-up. ${ }^{30}$

Even when different PTSD inventories (e.g., PTSD Scale, the World Health Organization Quality of Life instrument-Abbreviated version, the Beck Depression Inventory, etc.) were used to compare therapy results, telepsychiatry was still shown to provide significantly better outcomes compared to the control groups. ${ }^{23-37}$

It should be noted that while there are several psychotherapeutic strategies that are effective in managing PTSD patients, such as CBT, EMDR and prolonged exposure, all studies published so far on telepsychiatry have used CBT. The lack of direct contact between physician and patients, and the use of asynchronized telepsychiatry methods in several studies may hinder the implementation of EMDR or prolonged exposure, as they require active physician feedback. Further studies are hence still required especially on the effectiveness of telepsychiatry combined with these two other treatment methods, as are comparisons between the effectiveness of all three methods when delivered through telepsychiatry.

\section{Effectiveness in specific patient groups}

The use of telepsychiatry for PTSD has also been studied in specific patient groups, with telepsychiatry being found effective on both the elderly and children, for instance. ${ }^{38}$ Likewise, the method has been tested in both urban and rural areas ${ }^{33}$ and found to be effective.
Its use has also been found to be effective in studies conducted in various regions such as the Middle East, ${ }^{25,26}$ Asia, ${ }^{33}$ Europe, ${ }^{28,35}$ America, ${ }^{36}$ and Australia. ${ }^{30-32}$ Finally, telepsychiatry was able to manage PTSD regardless of the triggering event, and has been tested on patients with PTSD caused by war (veterans), ${ }^{25,26,34,36,39}$ natural disasters, ${ }^{33}$ post-partum, ${ }^{29}$ and other types of traumas.

Similarly to other psychiatric disorders, PTSD still raises stigma in many areas of the world. Hence, patients may fear seeking direct help and attend faceto-face consultations with mental health professionals even when they are accessible. Telepsychiatry can help in managing these patients as it can provide a secure and private environment to patients, from the comfort of their own place. This may help patients be more eager to seek help and increase interaction with mental health professionals.

\section{Long-term effects}

For telepsychiatry to be feasible, it should not only provide acute improvements but also remain effective in the long run. In the RCT conducted by Klein et al., at 3 months post-telepsychiatry for 10 weeks, $77 \%$ of the patients still reported improvements in their PTSD severity, with good patient satisfaction and an average doctor-patient interaction of fewer than 200 minutes. ${ }^{30}$

Furthermore, in another RCT led by Ivarsson et al. involving PTSD patients and using a fully Internet-based module, without any direct doctor-patient interaction, significant improvement in depression and anxiety as well as in post-therapy quality of life was reported, 
persisting even 1 year post-therapy. ${ }^{37}$ The study by Kersting et al. also reported similar improvement in symptoms remaining for one year post-therapy. ${ }^{29}$ Knaevelsrud \& Maercker reported that improvement of symptoms remained even at 18 months post-therapy. ${ }^{27}$

\section{Effect on quality of doctor-patient relationship and patient satisfaction}

One of the main impacts of telepsychiatry is the reduction of doctor-patient interaction. However, as shown in the study by Klein et al., doctor-patient relationship quality was reported to remain high, at $87.5 \% .{ }^{30}$

Spence et al. also reported that $81 \%$ of telepsychiatry users were satisfied with the care received and 95\% would recommend it to others. ${ }^{32}$ Knaelvelsrud et al. also reported a low dropout rate in the telepsychiatry group $(16 \%)$ and that $86 \%$ of users reported being satisfied. ${ }^{28}$ Furthermore, the study by Malhotra et al. involving children even showed a higher satisfaction rate in the telepsychiatry group compared to the face-to-face therapy group. ${ }^{38}$ Similar patient satisfaction findings were also reported by O'Reilly et al. ${ }^{24}$ and Wagner et al. ${ }^{26}$

\section{Length of therapy}

The therapeutic length of telepsychiatry for PTSD differed across the different studies evaluated. Some were performed for as short as 1 month $^{33}$ while some were 6 months long. ${ }^{23}$ However, it was shown that a minimum therapy of 1 month was already able to significantly reduce PTSD symptoms, with improvements remaining even post-therapy. ${ }^{33,37}$

On average, therapeutic time with telepsychiatry was also shorter compared to face-to-face therapy: the study by Klein et al. reported a therapeutic time of around 3 hours with telepsychiatry compared to 12 hours with face-to-face therapy. ${ }^{30}$ Shorter therapy durations were reported in other studies with as less as $<2$ hours in the study by Spence et al. ${ }^{32}$ These results were also supported by other authors, such as Wagner et al. ${ }^{26}$ and Knaevelsrud et al. ${ }^{34}$

\section{Web- and application-based telepsychiatry}

While telepsychiatry can facilitate remote faceto-face therapy with psychiatrists and psychologists through video conferencing, its greatest utility to provide treatment for the masses lies in the use of specialty software designed for patient self-help in managing PTSD. Software can be web- or applicationbased, including a step by step PTSD management curriculum for patients. For example, web-based My Trauma Recovery has been proven to be effective when implemented to help manage PTSD among earthquake victims in Wenchuan, China, in the year 2008. ${ }^{33}$ Telepsychiatry software has also been implemented successfully for other psychiatric disorders, including PTSD, in the Netherlands, through the web-based software Interapy. ${ }^{35}$ Mobile applications have also been utilized for the screening and management of PTSD patients, especially post-war veterans in the United States. ${ }^{39}$ Simpler forms of telepsychiatry such as through e-mail have also been found to be successful, as shown by Klein et al. ${ }^{31}$

\section{Cost-efficiency}

Only two studies have reported on the economic effects of telepsychiatry use in managing PTSD. Klein et al. reported that telepsychiatry was 3.7 times cheaper compared to face-to-face therapy. The costs of the two modalities were AUD 373 for telepsychiatry and AUD 1,380 for conventional face-to-face therapy. ${ }^{30}$ This result was also supported by O'Reilly et al., though at a lesser difference: cost analysis showed that utilizing telepsychiatry would save at least $10 \%$ per patient compared to face-to-face therapy (USD 394 vs. 439) and $16 \%$ per visit compared to the cost of in-person service (USD 265 vs. 315). This lower cost results from the fact that telepsychiatry reduces the need for travel and accommodation expenses, as well as higher psychiatrist fees to compensate for time lost due to travel. O'Reilly et al. also reported that the savings provided by telepsychiatry were proven to be greater than the technical costs of setting up and maintaining a telepsychiatry system. ${ }^{24}$

Notwithstanding, two studies reporting on an economic analysis of telepsychiatry underscored that these results should be viewed with caution and may not be generalizable to all settings. ${ }^{24,30}$ For instance, synchronized telepsychiatry is hypothetically most beneficial in settings with a large number of PTSD patients, located in remote or disaster-stricken areas with a low patient-to-mental health professional ratio. In urban areas or developed nations with adequate patient-to-mental health professional ratios, these systems may be more cost-effective compared to faceto-face therapy. ${ }^{24}$

However, the use of web- and application-based asynchronized telepsychiatry as explained earlier may be a cost-effective solution in most settings: even though this modality requires a substantial start-up investment, therapy costs are relatively low in the long run, as they require limited patient/mental health professional interaction. The rise of artificial intelligence systems in the future may further reduce these costs. 


\section{Practical implications}

The use of telepsychiatry in managing PTSD has been found to provide care for patients with comparable effectiveness and similar patient satisfaction as well as quality of doctor patient relationship when compared with face-to-face therapy. ${ }^{23,24,33,38}$

Improving accessibility and efficiency remains one of the main reasons for utilizing telepsychiatry. The growth of communication technologies such as the use of wireless technology, satellites, solar technology and fiber optics has made the implementation of telepsychiatry more feasible than ever. Reduced costs and therapeutic time as reported by various studies are also important benefits. Still, these results should be taken with caution, as only a few studies have evaluated the cost-effectiveness of telepsychiatry interventions. The lack of studies conducted in developing and less technologically developed areas are also concerning, as there may be additional setup costs and training required before telepsychiatry systems can be developed in these areas.

It is believed that telepsychiatry can improve not only the management of PTSD, but also screening and early diagnosis, as currently implemented by the Department of Veteran Affairs in the United States, and also for post-disaster areas, such as in Pakistan. ${ }^{40,41}$ To date, the majority of studies originate from developed nations, especially Europe, and further studies are needed to examine the efficacy of telepsychiatry in developing and underdeveloped nations in Asia and Africa, which are lacking in psychiatric services.

Similarly to the implementation of new technologies in other fields, the application of telepsychiatry still faces several barriers, including limited connectivity, lack of human resources and lack of telepsychiatry equipment. In addition, e-health guidelines and regulations need to be developed to address issues such as doctor-patient confidentiality, data privacy, etc. This review has shown that studies tend to focus only on parameters of efficacy, rarely analyzing the economic aspects of telepsychiatry (only two studies provided an economic analysis). Therefore, economic feasibility remains an important aspect to look into, especially when considering the implementation of telepsychiatry in developing nations and the coverage of this system by insurance plans. When these barriers can be addressed, the implementation of telepsychiatry could hopefully be able to make treatment for PTSD and other psychiatric disorders more affordable and reachable to the masses.

\section{Limitations}

This review article suffers limitations in only being able to synthesize previously published journal articles and trials that are accessible to the authors. It should be noted that the studies included were based on published reports and take into account that studies reporting positive results are more readily accepted for publication as compared with studies reporting negative results. Also, most studies reviewed originate from developed countries, and there is a lack of studies reporting on telepsychiatry use in developing nations such as Asia and Africa, where it is best utilized to help bridge the currently low patient-to-mental health professional ratio. Furthermore, studies on its utilization in less technologically developed areas, with low literacy rates, as well as remote in location are also lacking in number.

\section{Conclusions}

Various studies have pointed to telepsychiatry as an effective and efficient way to manage PTSD. The quality of care given by telepsychiatry, both through video conferencing and web- and application-based, is comparable to that of face-to-face therapy, although most studies published so far are from developed nations. Patient satisfaction and quality of doctor-patient relationship also remain high, with therapeutic time comparable to that of face-to-face therapy. Countries, especially those with a low patient-to-mental health professional ratio, should be encouraged to develop telepsychiatry systems to manage PTSD.

\section{Disclosure}

No conflicts of interest declared concerning the publication of this article.

\section{References}

1. Javidi $\mathrm{H}$, Yadollahie M. Post-traumatic stress disorder. Int J Occup Environ Med. 2012;3:2-9.

2. World Health Organization. WHO releases guidance on mental health care after trauma [online]. 2013 [cited 2018 Aug 24]. http://www.who.int/mediacentre/news/releases/2013/trauma_ mental_health_20130806/en/

3. Republic of Indonesia, Ministry of Health. National Basic Health Survey. Jakarta: Ministry of Health; 2018.

4. Republic of Indonesia, State Intelligence Agency. Waspada terhadap pelecehan seksual pada anak usia dini [online]. 
2018 [cited 2018 Sep 10]. http://www.bin.go.id/awas/ detil/458/4/20/07/2018/waspada-terhadap-pelecehan-seksualpada-anak-usia-dini

5. Republic of Indonesia, Indonesian National Police. National Criminal Information Center [online]. 2018 [cited 2018 Sep 10]. https://pusiknas.polri.go.id/kamtibmas.html

6. Republic of Indonesia, Ministry of Transportation. Transportation Statistics Book 1 Year 2017. Jakarta: Ministry of Transportation; 2017.

7. Chandra ZA. Pengaruh dukungan sosial keluarga terhadap kesembuhan penderita post traumatic stress disorder (PTSD) di pusat pelayanan terpadu (ppt) "mawar" rsud dr. fauziah bireuen tahun 2009 [thesis]. Medan: Universitas Sumatera Utara; 2009.

8. Erwina I. The influence of cognitive behavior therapy toward of post traumatic stress disorder on post earthquake population in air tawar barat urban village, north padang, west sumatera [thesis]. Depok: Universitas Indonesia; 2010.

9. Frankenberg E, Nobles J, Sumantri C. Community destruction and traumatic stress in post-tsunami Indonesia. J Health Soc Behav. 2012;53:498-514.

10. Sadock B, Sadock V. Kaplan and Sadock's synopsis of psychiatry. 11th ed. Alphen aan den Rijn: Wolters Kluwer; 2014.

11. National Institute of Mental Health. National Institute of Mental Health | Post-Traumatic Stress Disorder (PTSD) [online]. [cited 2018 Oct 24]. http://www.nimh.nih.gov/health/topics/posttraumatic-stress-disorder-ptsd/index.shtml

12. Bomyea J, Lang AJ. Emerging interventions for PTSD: Future directions for clinical care and research. Neuropharmacology. 2012;62:607-16.

13. American Psychiatric Association. Diagnostic and Statistical Manual of Mental Disorders (DSM), Fifth Edition. Arlington: American Psychiatric Association; 2013.

14. Central Java Provincial Research and Development Department. [Post traumatic stress disorder (post disaster traumatic stress disorder) in Central Java]. Semarang: Central Java Provincial Government; 2008.

15. Lubis FY, Dalimunthe KL. Impact of disaster event on student's cognition achievement in SMAN 1 Pangalengan and SMA Aliyah Pangalengan, West Java, Indonesia. GSTF J Law Soc Sci. 2012:1:53-6.

16. Sebayang SK, Mawarpury M, Rosemary R. Jakarta Post [online]. 2018 [cited 2018 Oct 24]. https://www.thejakartapost.com/ academia/2018/11/06/less-than-1000-psychiatrists-for-260million-indonesians.html

17. World Health Organization. Telemedicine: Opportunities and developments in member states. Geneva: World Health Organization; 2010.

18. Solar Surya Indonesia. Solar Surya Indonesia [online]. 2013 [cited 2018 Oct 24]. http://solarsuryaindonesia.com/news/ mengintip-teknologi-mobil-tanggap-bencana-besutan-kominfo

19. InSight. Scheduled telepsychiatry services [online]. 2014 [cited 2018 October 24]. http://insighttelepsychiatry.com/scheduledtelepsychiatry-services-2/

20. Vestal C. In rural SC, telepsychiatry cuts wait times for mental health exams from 4 days to 10 hours [online]. Medcity News. 2014 Jun 27 [cited 2018 Oct 24]. http://medcitynews.com/2014/06/ telepsychiatry-reduces-wait-times-psyciatric-exams-4-days-10hours-sc-hospital/

21. World Health Organization. Global diffusion of eHealth: making universal health coverage achievable. Geneva: WHO/Global Observatory for eHealth; 2016.

22. Zafar A. International Telecommunication Union [online]. 2011 [cited 2018 Oct 24]. http://www.itu.int/ITU-D/ emergencytelecoms/events/Zimbabwe 2011/Applications\%20 of\%20telemedicine\%20in\%20Emergencies_Harare_2011_1.pdf

23. Germain V, Marchand A, Bouchard S, Drouin MS, Guay S. Effectiveness of cognitive behavioural therapy administered by videoconference for posttraumatic stress disorder. Cogn Behav Ther. 2009;38:42-53.

24. O'Reilly R, Bishop J, Maddox K, Hutchinson L, Fisman M, Takhar J. Is telepsychiatry equivalent to face-to-face psychiatry? results from a randomized controlled equivalence trial. Psychiatric Serv. 2007;58:836-43.
25. Wagner B, Schulz W, Knaevelsrud C. Efficacy of an Internet-based intervention for posttraumatic stress disorder in Iraq: A pilot study. Psychiatry Res. 2012;195:85-8.

26. Wagner B, Brand J, Schulz W, Knaevelsrud C. Online working alliance predicts treatment outcome for posttraumatic stress symptoms in Arab war-traumatized patients. Depress Anxiety. 2012;29:646-51.

27. Knaevelsrud C, Maercker A. Long-term effects of an internetbased treatment for posttraumatic stress. Cogn Behav Ther. 2010;39:72-7

28. Knaevelsrud C, Maercker A. Internet-based treatment for PTSD reduces distress and facilitates the development of a strong therapeutic alliance: a randomized controlled clinical trial. BMC Psychiatry. 2007;7:13.

29. Kersting A, Dolemeyer R, Steinig J, Walter F, Kroker K, Baust K, et al. Brief Internet-based intervention reduces posttraumatic stress and prolonged grief in parents after the loss of a child during pregnancy: A randomized controlled trial. Psychother Psychosom. 2013;82:372-81.

30. Klein B, Mitchell J, Abbott J, Shandley K, Austin D, Gilson K. A therapist-assisted cognitive behavior therapy internet intervention for posttraumatic stress disorder: Pre-, post- and 3-month followup results from an open trial. J Anxiety Disord. 2010;24:635-44.

31. Klein B, Mitchell J, Gilson K, Shandley K, Austin D, Kiropoulos $L$, et al. A therapist-assisted Internet-based CBT intervention for posttraumatic stress disorder: Preliminary results. Cogn Behav Ther. 2009;38:121-31.

32. Spence J, Titov N, Dear BF, Johnston L, Solley K, Lorian C, et al. Randomized controlled trial of Internet-delivered cognitive behavioral therapy for posttraumatic stress disorder. Depress Anxiety. 2011;28:541-50.

33. Wang Z, Wang J, Maercker A. Chinese My Trauma Recovery, A web-based intervention for traumatized persons in two parallel samples: Randomized controlled trial. J Med Internet Res. 2013;15:e213.

34. Knaevelsrud C, Brand J, Lange A, Ruwaard J, Wagner B. Webbased psychotherapy for posttraumatic stress disorder in wartraumatized Arab patients: Randomized controlled trial. J Med Internet Res. 2015;17:e71.

35. Lange A, Rietdijk D, Hudcovicova $M$, van de Ven JP, Schrieken B, Emmelkamp PM. Interapy: a controlled randomized trial of the standardized treatment of posttraumatic stress through the internet. J Consult Clin Psychol. 2003;71:901-9.

36. Engel CC, Litz B, Magruder KM, Harper E, Gore K, Stein N, et al. Delivery of self training and education for stressful situations (DESTRESS-PC): A randomized trial of nurse assisted online selfmanagement for PTSD in primary care. Gen Hosp Psychiatry. 2016;37:323-8.

37. Ivarsson D, Blom M, Hesser H, Carlbring P, Enderby P. Guided internet-delivered cognitive behavior therapy for post-traumatic: A randomized controlled trial. Internet Interventions. 2014;1:3340.

38. Malhotra S, Chakrabarti S, Shah R. Telepsychiatry: Promise, potential, and challenges. Indian J Psychiatry. 2013;55:3-11.

39. US Department of Veteran Affairs. US Department of Veteran Affairs [online]. 2016 [cited 2018 Oct 24]. http://www.ptsd. va.gov/public/materials/apps/PTSDCoach.asp

40. Norris AC. Essentials of Telemedicine and Telecare. West Sussex: John Wiley and Sons; 2002.

41. Ministry of Information and Technology Pakistan. Telemedicine: MoIT- Health Net [online]. 2008 [cited 2018 Oct 24]. http://www. telemedicine.pk/disaster\%20management.html

\section{Correspondence:}

Anthony Paulo Sunjaya

Faculty of Medicine, Tarumanagara University

Jl. Letjen S. Parman No. 1

11440 - Jakarta - Indonesia

E-mail: anthony@doctors.web.id 